\title{
Contributors to This Issue
}

Heather Gumbert is associate professor of history at Virginia Tech (Department of History, 220 Stanger Street, Blacksburg, VA 24060; email: hgumbert@vt.edu). She earned her PhD in May 2006 from the University of Texas, Austin. She is the author of Envisioning Socialism: Television and the Cold War in the German Democratic Republic (2014). Her current work explores the complex and contradictory role of the Berlin Wall in narratives of Cold War Europe. She continues to explore the transnational importance of television in the twentieth-century world, specifically the emergence and growth of industrial television centers in cities that became significant nodes in postwar networks of circulation and exchange.

Samuel Clowes Huneke is assistant professor of history at George Mason University (Department of History and Art History, 3200 Horizon Hall, Fairfax, VA 22030; email: shuneke@gmu.edu). He was awarded his PhD in June 2019 from Stanford University. He is the author of States of Liberation: Gay Men between Dictatorship and Democracy in Cold War Germany (2022). His current work explores democratization and denazification efforts in occupied Germany.

Andrea Orzoff is associate professor of history and Honors College faculty fellow at New Mexico State University (Department of History, MSC 3H, Las Cruces, NM 88003; email: aorzoff@nmsu.edu). She is the author of Battle for the Castle: The Myth of Czechoslovakia in Europe, 1914-1948 (2009). She is currently completing a book titled "Music in Flight: Refugees, Exiles, Fugitives, and European Music in Latin America, 1933-1960.”

Joseph Sproule was awarded his PhD in March 2019 from the University of Toronto (email: joseph.sproule@utoronto.ca). His current research explores mercenaries, the social and labor history of soldiering, wartime migration and diaspora, military cultures, the economy of war, and state formation and destruction in early modern Livonia and Scandinavia.

Peter Thompson is a PhD candidate in the History Department at the University of Illinois, Urbana-Champaign (Department of History, 309 Gregory Hall, Urbana, IL 61801; email pbthomp2@illinois.edu). His current work examines the ways in which poison gas and the gas mask helped shape German interwar understandings of risk, danger, management, and mastery as well as the import of these subjective categories for reconceptualizing the individual, the nation, and the atmospheric environment. 


\section{FORTHCOMING}

Volume 54

Number 3

2021

ARTICLES

The "Golden City" under Embargo: Prague's International Trade during the Hussite Wars, 1420-36

Alexandra Kaar

Anticommunism and Détente: Mindszenty, the Catholic Church, and

Hungarian Émigrés in West Germany, 1972

Árpád von Klimó

"Greetings from the Apocalypse": Race, Migration, and Fear after

German Reunification

Christopher A. Molnar

FEATURED REVIEW

Peter Longerich, Hitler: A Biography

Nathan Stoltzfus

BoOk Reviews 


\section{ENEMES of the

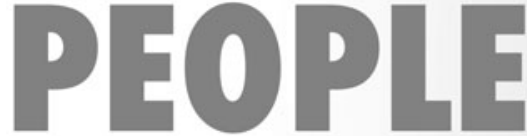 \\ HITLER'S CRITICS \\ AND THE GESTAPO}

J. RYAN STACKHOUSE

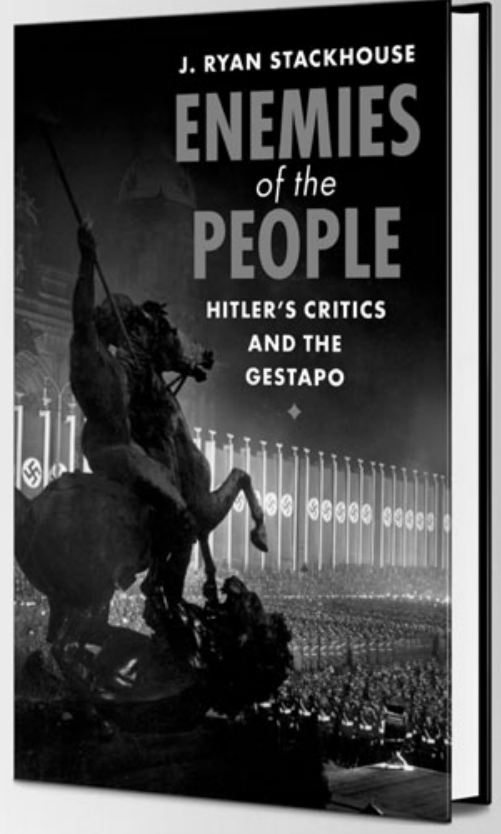

"Memorable and chilling. Stackhouse's eminently readable book offers fresh insights into political policing in Nazi Germany and helps us to better understand how the Gestapo's rule of terror worked."

Robert Gerwarth, University College Dublin

"Stackhouse's focus on the Gestapo's 'selective enforcement' broadens our understanding of policing the Volksgemeinschaft and of the Nazi state. His impressive book also has much to say about visions of an 'authoritarian rule of law' in general and should be required reading." Katrin Paehler, Illinois State University 


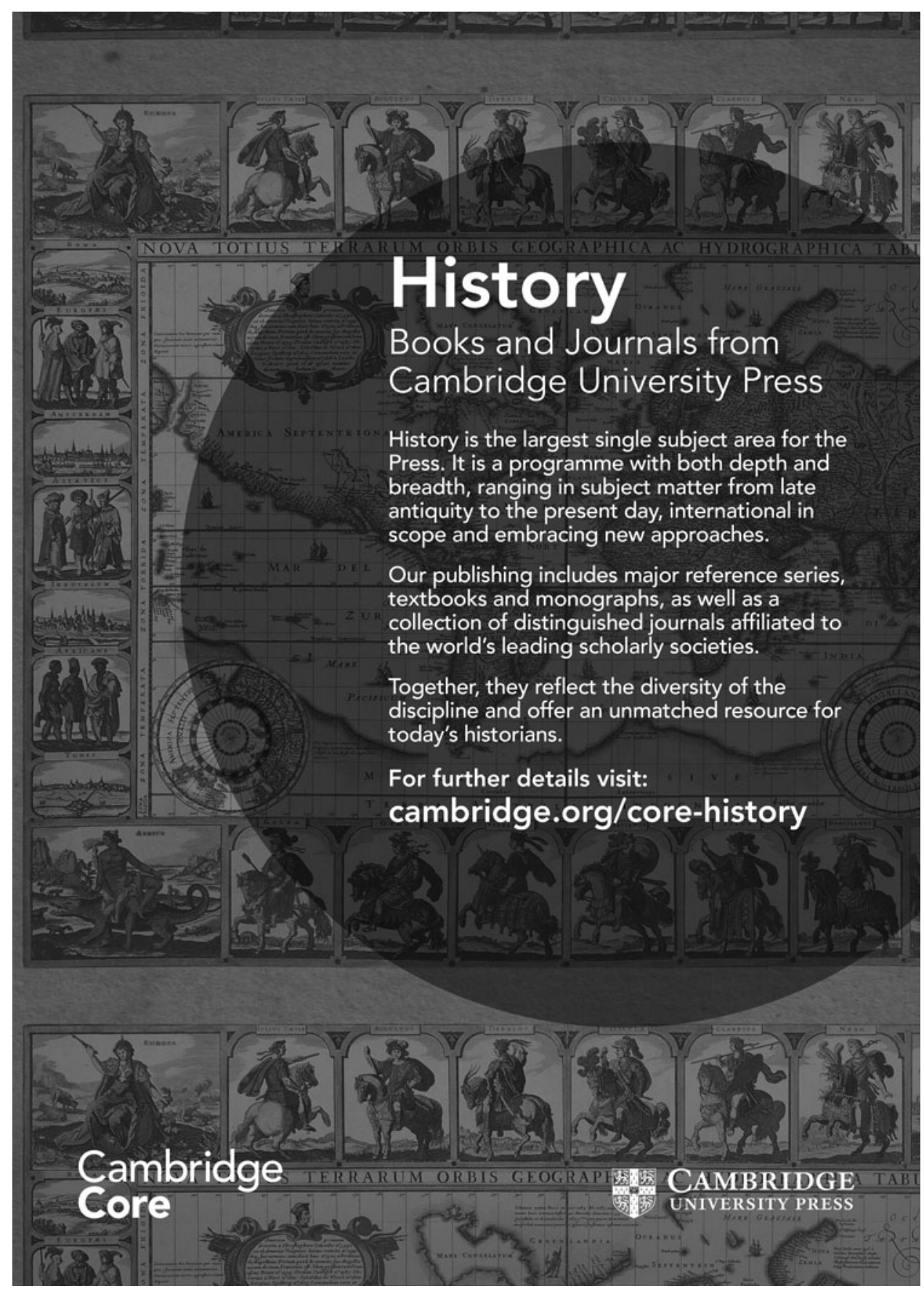




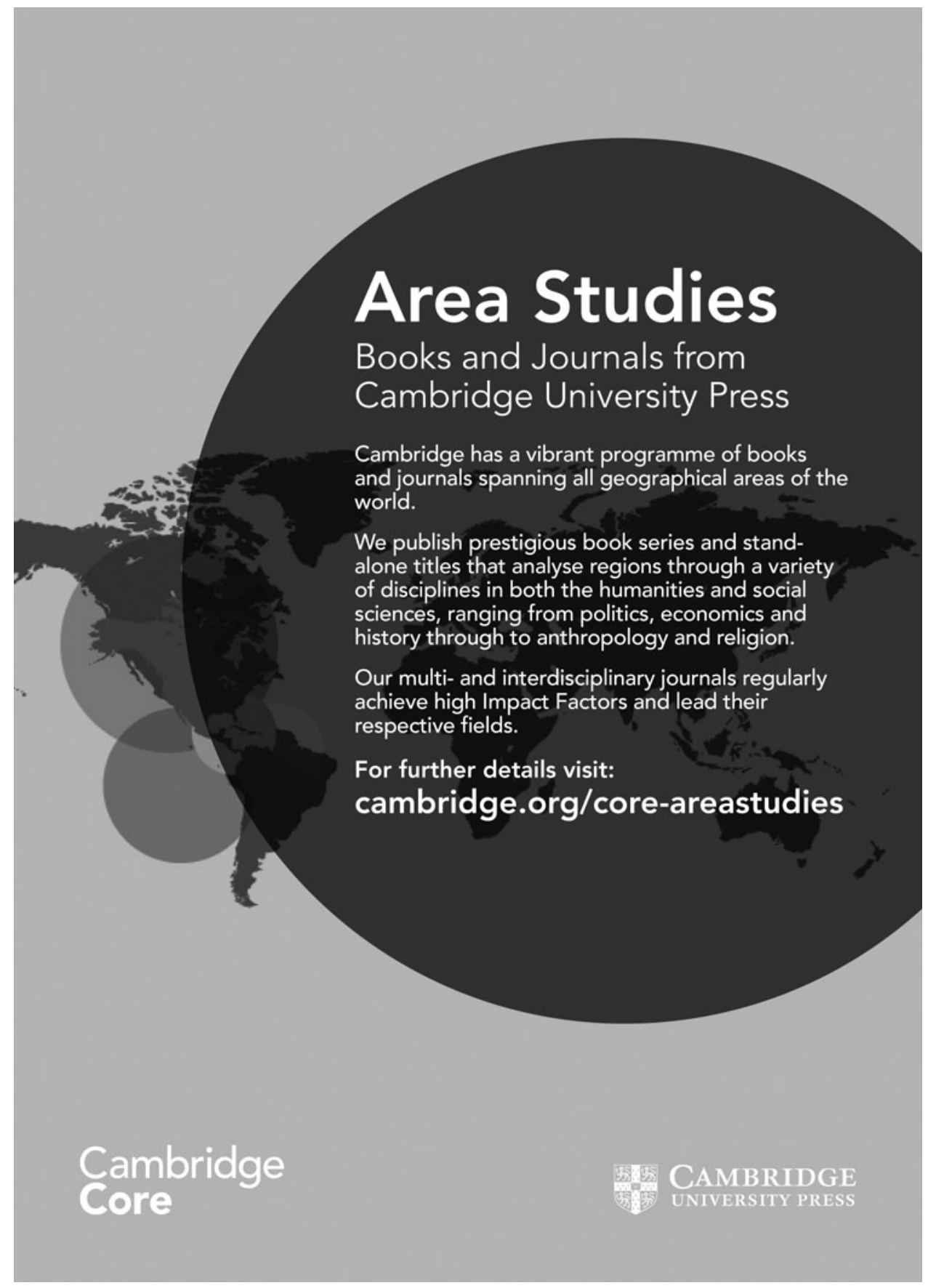


Published since 1968, Central European History is the primary venue for scholarly exchange and debate of central Europe's diverse and complex history. The journal publishes on a range of topics, bringing research articles, book and film reviews and review essays, discussion fora, and other forms of scholarly writing to a broad audience of specialists and non-specialists in four issues per year. Spanning the medieval to the modern period, CEH offers a space for creative approaches to understanding the region's past, while continually reassessing its conceptual and geographic boundaries and their representations. $\mathrm{CEH}$ publishes work related to German-speaking and German-identified peoples, as well as work on non-German-speakers in the historic states and regions of central Europe, including the Habsburg lands, Austria, and Switzerland. The journal welcomes submissions that expand and de-territorialize the region's historic frames of reference, taking identity, language, and space — and the complex links and ruptures among them—seriously. CEH perennially engages anew the old question, "what and where is central Europe?"

\section{Editorial Policy}

Central European History welcomes manuscripts using all approaches to history and dealing with all historical periods. Because space is limited, the journal does not accept articles that have been or will be published elsewhere. Most research articles are 10-12,000 words, including notes. Manuscripts submitted to Central European History should not be under consideration by any other journal. If the Editor learns that an article Central European History is considering is also under submission at another journal, Central European History's consideration will cease. Book Reviews range from 800-1000 words and are commissioned by the Associate Editor. Unsolicited book reviews are not accepted. Authors may submit articles in languages other than English but only after consulting the Editor. Some financial support may be available to defray the costs of translation into English if a manuscript is accepted.

All article manuscripts should be submitted via ScholarOne (https://mc. manuscript- central. $\mathrm{com} / \mathrm{ccc})$. Authors should please take care to remove any information that might identify them as author, and follow the prompts in ScholarOne to make their manuscripts anonymous. The entire text of all manuscripts, including footnotes and headings, must be prepared in double-spaced typescript with generous margins to allow for copyediting. Footnotes must be numbered consecutively.

All materials will be edited to conform with The Chicago Manual of Style in matters of punctuation, capitalization, and format. Final decisions on style remain with the editor.

Correspondence for the editor should be sent to:

E-mail: ceh@utk.edu,or

\section{The Editor, Central European History}

University of Tennessee, Knoxville

Department of History

Dunford Hall, 6th Floor

Knoxville, TN 37996

USA

Correspondence for the associate editor, book reviews should be sent to:

E-mail: ceh@ohio.edu, or

The Associate Editor, Central European History

Department of History

421 Bentley Annex

Ohio University

Athens, $\mathrm{OH} 45701$

USA 


\section{CENTRAL EUROPEAN HISTORY}

Volume 54 | Number 2 | June 2021

\section{ARTICLES}

Livonian Mercenary Warfare and Fiscal Responses to the Military Crisis of 1558-1561

Joseph Sproule

The Pale Death: Poison Gas and German Racial Exceptionalism, 1915-1945

Peter Thompson

Heterogeneous Persecution: Lesbianism and the Nazi State

Samue/ Clowes Huneke

Citizen of the Staatsoper: Erich Kleiber's Musical Migration

326

Andrea Orzoff

REVIEW ESSAY

BOOK REVIEWS

361

CONTRIBUTORS TO THIS ISSUE

FORTHCOMING

\section{Cambridge Core}

